\title{
BMI prediction within a Korean population
}

\author{
Jin Sol Lee ${ }^{1,2}$, Hyun Sub Cheong Corresp., ${ }^{3}$, Hyoung-Doo Shin Corresp. 1, 2, 3 \\ 1 Research Institute for Basic Science, Sogang University, Seoul, Republic of Korea \\ 2 \\ partment of Life Science, Sogang University, Seoul, South Korea \\ 3 Department of Genetic Epidemiology, SNP Genetics, Inc., Seoul, Republic of Korea \\ Corresponding Authors: Hyun Sub Cheong, Hyoung-Doo Shin \\ Email address: chhs@snp-genetics.com, hdshin@sogang.ac.kr
}

Background. Body Mass Index (BMI) is widely regarded as an important clinical trait for obesity and other diseases such as Type 2 diabetes, coronary heart disease, and osteoarthritis.

Methods. This study uses 6,011 samples of genotype data from ethnic Korean subjects. The data was retrieved from the Korea Association Resource. To identify the BMI-related markers within the Korean population, we collected genome-wide association study (GWAS) markers using a GWAS catalog and also obtained other markers from nearby regions. Of the total 6,011 samples, 5,410 subjects were used as part of a single nucleotide polymorphism (SNP) selection set in order to identify the overlapping BMIassociated SNPs within a 10 -fold cross validation.

Results. We selected 9 SNPs (rs12566985 (FPGT-TNNI3K), rs6545809 (ADCY3), rs2943634 (located near LOC646736), rs734597 (located near TFAP2B), rs11030104 (BDNF), rs7988412 (GTF3A), rs2241423 (MAP2K5), rs7202116 (FTO), and rs6567160 (located near LOC105372152) to assist in BMI prediction. The calculated weighted genetic risk scores based on the selected 9 SNPs within the SNP selection set were applied to the final validation set consisting of 601 samples. Our results showed upward trends in the BMI values $(P<0.0001)$ within the 10 -fold cross validation process for $R^{2}>0.22$. These trends were also observed within the validation set for all subjects, as well as within the validation sets divided by gender $\left(P<0.0001, R^{2}>0.46\right)$.

Discussion. The set of 9 SNPs identified in this study may be useful for prospective predictions of BMI. 


\section{Title Page}

2

\section{BMI Prediction within a Korean Population}

4

$7 \quad{ }^{1}$ Department of Life Science, Sogang University, Baekbumro 35, Mapo-gu, Seoul, Republic of

$8 \quad$ Korea

$9 \quad{ }^{2}$ Research Institute for Basic Science, Sogang University, Seoul, 121-742, Republic of Korea

${ }^{3}$ Department of Genetic Epidemiology, SNP Genetics, Inc., Taihard building 1007, Sogang

11 University, Baekbumro 35, Mapo-gu, Seoul, Republic of Korea

*Address correspondences to: Dr. Hyun Sub Cheong, Department of Genetic Epidemiology, SNP

Genetics, Inc., Taihard building 1007, Sogang University, Baekbumro 35, Mapo-gu, Seoul 04107,

16 Republic of Korea. Tel: 82-2-3273-1671; Fax: 82-2-3273-1680; E-mail: chhs@snp-genetics.com;

17 Dr. Hyoung Doo Shin, Department of Life Science, Sogang University, Baekbumro 35, Mapo-gu,

18 Seoul, 04107, Republic of Korea. Tel: 82-2-3273-1671; Fax: 82-2-3273-1680; E-mail:

19 hdshin@sogang.ac.kr 
21

\section{Abstract}

Background. Body Mass Index (BMI) is widely regarded as an important clinical trait for obesity and other diseases such as Type 2 diabetes, coronary heart disease, and osteoarthritis.

Methods. This study uses 6,011 samples of genotype data from ethnic Korean subjects. The data was retrieved from the Korea Association Resource. To identify the BMI-related markers within the Korean population, we collected genome-wide association study (GWAS) markers using a GWAS catalog and also obtained other markers from nearby regions. Of the total 6,011 samples, 5,410 subjects were used as part of a single nucleotide polymorphism (SNP) selection set in order to identify the overlapping BMI-associated SNPs within a 10 -fold cross validation.

Results. We selected 9 SNPs (rs12566985 (FPGT-TNNI3K), rs6545809 (ADCY3), rs2943634 (located near LOC646736), rs734597 (located near TFAP2B), rs11030104 (BDNF), rs7988412 $(G T F 3 A), \quad r s 2241423$ (MAP2K5), $\quad r s 7202116$ (FTO), and rs6567160 (located near LOC105372152) to assist in BMI prediction. The calculated weighted genetic risk scores based on the selected 9 SNPs within the SNP selection set were applied to the final validation set consisting of 601 samples. Our results showed upward trends in the BMI values $(P<0.0001)$ within the 10 fold cross validation process for $\mathrm{R}^{2}>0.22$. These trends were also observed within the validation set for all subjects, as well as within the validation sets divided by gender $\left(P<0.0001, \mathrm{R}^{2}>0.46\right)$.

Discussion. The set of 9 SNPs identified in this study may be useful for prospective predictions of BMI. 


\section{Introduction}

Body Mass Index (BMI) is widely used as a diagnostic measurement of obesity which in turn is related to various diseases such as heart disease, Type 2 diabetes, hypertension, and osteoarthritis (1998). Because of the important role BMI plays, numerous genome-wide association studies (GWAS) have been conducted to identify BMI-associated single nucleotide polymorphisms (SNPs). From these studies, researchers have identified several significant genes found to be related to BMI such as FTO, BDNF, and $M C 4 R$, among others (Felix et al. 2016; Locke et al. 2015; Speliotes et al. 2010). Further replication studies across various populations have also reported significant associations between these genes and BMI (Bonaccorso et al. 2015; Munoz-Yanez et al. 2016; Neocleous et al. 2016). Using these results, several studies have developed prediction models for BMI and obesity among various ethnic groups (Bae et al. 2016; Hung et al. 2015; Peterson et al. 2014).

Although several BMI or obesity prediction models have been developed, these models have not been applicable to the Korean population. One issue is the significant genetic difference between the Korean population and other populations. The significance of many BMI-associated SNPs in GWAS conducted on other populations have not been replicated in the Korean population. Moreover, although SNPs in the prediction models have shown significant associations with BMI, the effective size difference of these prediction models are unsuitable for the Korean population. These results suggest a need for new BMI prediction methods that can be applied to the Korean population.

There are several methods for predicting specific diseases or clinical traits using multiple loci. The weighted genetic risk score (wGRS) is one simple and effective method for constructing SNP 
63 sets integrating the multiplied risk allele number of each SNP with the regression coefficient.

64 Several previous studies have shown the effectiveness of using the wGRS to build a prediction 65 model for various diseases (Chen et al. 2011; Palmieri et al. 2017; Thanassoulis et al. 2012).

66 In the present study, we aimed to identify BMI-associated SNPs for the Korean population 67 using genotype data obtained from the Korea Association Resource (KARE) (Cho et al. 2009). To 68 increase the validity of the study, we used the significant SNPs identified in previous BMI-related 69 GWA-studies. Furthermore, we conducted SNP selection based on 10-fold cross validation used 70 in conjunction with the wGRS on a SNP selection set consisting of 5,410 samples from Korean 71 subjects. The wGRS of the selected SNPs was applied to an independent validation set consisting 72 of 601 samples. 


\section{Method}

\section{Study subjects}

The genotype data used in the present study were obtained from the KARE project (Cho et al. 2009). This study approved by Public Institutional Bioethics Committee designated by the Ministry of Health and Welfare (P01-201502-31-002). To ensure data quality, we eliminated samples and SNPs with a call rate of less than $98 \%$. SNPs with a MAF of less than 0.05 were also excluded from our data set. A total of 6,011 samples (2,903 male and 3,108 female) were used for statistical analyses. The 6,011 samples were divided into one set of 5,410 samples (2,613 male and 2,797 female) to be used as a SNP selection set for 10-fold cross-validation and one set of 601 samples (290 male and 311 female) to be used as a validation set. The G*Power Version 3.1 software (Universität Kiel, Germany) (Faul et al. 2009) was used to calculate statistical powers. The software found both the test set $(\mathrm{n}=541)$ and validation set $(\mathrm{n}=601)$ to be at over $95 \%$. Details on the number of samples are summarized in Supplementary Table 1.

\section{SNP pruning for statistical analyses}

In order to identify reliable SNPs for BMI prediction, we first identified the significant SNPs reported in prior BMI-related GWAS which had been validated by at least one secondary replication study. Then, we obtained the genotype data for the collected GWAS markers including other markers from nearby regions $( \pm 10 \mathrm{~kb}$ from the GWAS markers $)$ from the KARE data $(10,568$ SNPs). To avoid the issue of high linkage disequilibrium (LD) found in the wGRS method, the LD coefficients $\left(\mathrm{r}^{2}>0.2\right)$ of all pairs of SNPs were calculated using the Haploview software (Barrett et al. 2005). Finally, we obtained a set of 193 SNPs which showed significant relationships with 
96

97

98

BMI in the previous GWA-studies. We also identified SNPs in the regions near the reported SNPs. The $P$-values obtained from regression analyses conducted on the training set $(\mathrm{n}=4,869)$ were used to identify the most significant SNPs. The regression analysis was conducted using the GoldenHelix SVS8 software (Bozeman, MT, USA).

\section{SNP selection for BMI prediction}

From the SNP selection set (5,410 samples), 10-fold cross validation was conducted on the genotype data (training set of 4,869 subjects and test set of 541 subjects) to identify the SNPs to be used for BMI prediction. The natural log-transformed BMI values were used for statistical analyses. SNPs were selected as tagging SNPs for each training set only where their $P$-value was less than 0.05 and where they were identified to be significant SNPs with the same LD. The wGRS was calculated as the sum of the number of BMI-increasing alleles multiplied by the regression slope across all variants in each set as previously described ( $\sum_{\mathrm{i}=1}^{\mathrm{n}}$ Number of risk allele in SNPi $\times$ Weighti; $\mathrm{n}=$ number of SNP, Weight: regression slope value of $\mathrm{SNP}_{\mathrm{i}}$ ) (Hung et al. 2015). Then, we divided the wGRS of each set into 5 sections in a subject number-dependent manner and calculated the average BMI values of the sections to obtain the trend lines. After 10-fold cross validation, we selected 9 SNPs which overlapped across all training sets (Supplementary Table 2). Detailed information and analysis of the selected SNPs are detailed in Table 1 and Figure 1, respectively. The application process of wGRS using the selected 9 SNPs to the independent validation set was the same as described above. The overall $P$-values for the trend lines were calculated using GraphPad Software (La Jolla California USA) for all BMI values of each wGRS section. 


\section{Results}

119

120

The average age and average BMI values were slightly higher among female subjects than

male subjects across the complete set of samples, the SNP selection set, and the validation set.

Detailed information of the subjects is given in Figure 1 and Supplementary Table 1.

An analysis flow chart for the present study is displayed in Figure 1. The results of each set

of 10 -fold cross-validations show that the BMI values increased in all training sets and

corresponding test sets with respect to wGRS for $P$-values of $<0.0005$ and $\mathrm{R}^{2}$ of $>0.2$. The detailed

$P$-values of the SNPs and BMI trend lines for the training set and test set are detailed in

Supplementary Table 2 and Supplementary Figure 1, respectively.

128

Of the 28 SNPs applied to the cross-validation process, we selected only 9 SNPs which overlapped across all 10-fold cross-validations conducted for BMI prediction. The 9 SNPs are listed in Table 1 with their location, allele information, and genotype data as obtained from the SNP selection set. We calculated the wGRS using the 9 SNPs based on the SNP selection set $(n=5,410)$ and applied the wGRS to final validation set $(n=601)$. As expected, the results of the SNP selection set showed upward BMI trends across all three groups with $P$-values of 0.002 for the complete set, 0.01 for males, and 0.008 for females, respectively (data not shown).

To confirm the upward BMI trends and significance of SNPs, we randomly re-constructed an additional 9 sets which had the same SNP selection set size $(n=5,410)$ and final validation set size

$137(\mathrm{n}=601)$. The results showed that the 9 SNPs were significantly related to BMI across all additionally created sets $(P<0.05)$. The detailed range of $P$-values is listed in Table 1 . The standard curves for the SNP selection sets also showed significant association with BMI $(P<$ 0.0001 ) with $\mathrm{R}^{2}$ values of 0.9729 for the complete set, 0.9296 for males, and 0.9598 for females 
141 (Figure 2).

142 Application results of the wGRS to the final validation sets showed increasing trends with a

$143 P$-value of $<0.0001$ and $\mathrm{R}^{2}$ value of 0.6766 (Figure $2 \mathrm{~A}$ ). This trend was also observed in the 144 analyses for male $\left(P\right.$-value of $<0.0001$ with $\mathrm{R}^{2}$ of 0.5359$)$ and female populations $(P$-value of $145<0.0001$ with $\mathrm{R}^{2}$ of 0.4632 ) (Figure $2 \mathrm{~B}$ and Figure $2 \mathrm{C}$ ). 


\section{Discussion}

After the first large-scale GWAS was conducted using the KARE data with respect to several clinical traits (Cho et al. 2009), numerous follow-up studies have also been performed on independent cohorts. Of these studies, one reported that one SNP (rs17178527 in LOC729076) was found to be significantly associated with BMI after applying Bonferroni correction with a $P$ value of $1.45 \times 10^{-7}$ (Bae et al. 2016). Several SNPs across various genes including FTO, BDNF, and MC4R were also found to be associated with BMI. Additional replication studies have consistently confirmed the significance of these SNPs in genes (Cha et al. 2011; Cha et al. 2008; Hong et al. 2012).

In the present study, we aimed to identify BMI-related SNPs using the KARE data in order to build a SNP set for BMI prediction. It is widely accepted that the influence of SNPs on BMI is small. Therefore, our study focused on increase of validity of using SNPs to understand BMI. We applied the wGRS to various test sets including validation sets and consistently found an increase in BMI trends. The $\mathrm{R}^{2}$-values of the standard curves in the final validations $(>0.4)$ suggest that the 9 selected SNPs were not perfect indicators of BMI, but were significant enough to be considered for BMI prediction within the Korean population. Our results also indicated that the selected markers were not only associated to BMI within other populations but also within the Korean population.

There have been only a few studies conducted on BMI and/or obesity prediction in adulthood. We sought to find whether the 9 SNPs used in our models had been included in previous studies. From our research, we found that $r s 2241423$ in $M A K 2 K 5$ had been selected as one of SNPs for an obesity model for Caucasian populations (Hung et al. 2015). In addition, rs11030104 in BDNF 
169 had been used in one study for BMI prediction within Korean populations (Bae et al. 2016). Two

170 other BDNF SNPs (rs6265 and rs4923461) had been used in prediction models and had been found

171 to be in high LD $\left(\mathrm{r}^{2}>0.8\right)$ with $r s 11030104$. Similarly, SNPs in FTO (rs9939609 or rs3751812,

$\left.172 \mathrm{r}^{2}>0.8\right)$ and $A D C Y 3\left(\right.$ rs6545814 or $\left.r s 10182181, \mathrm{r}^{2}>0.8\right)$ were used in other models (Bae et al. 2016;

173 Hung et al. 2015; Sandholt et al. 2010). These results serve as evidence to support the validity of

174 our results. In addition, comparison of two studies conducted on Korean populations suggest that 175 at least 3 SNPs ( $r s 11030104$ in $B D N F$, rs6545814 in $A D C Y 3$, and rs9939609 in FTO) might play 176 crucial roles in BMI prediction for Korean populations.

177 There have been numerous reports which showing significant associations between BMI and SNPs in $B D N F, A D C Y 3$, and $F T O$. The functional role of several SNPs of various genes have also 179 been revealed. Of the 3 SNPs $r s 11030104$, rs6545814, and $r s 9939609$ which had been selected in both previous and the present study using Korean populations, rs 11030104 in BDNF was found to influence eating behavior, causing lower satiety responsiveness in children (Monnereau et al. 2017). In addition, a previous meta-analysis reported that $r s 6545814$ in $A D C Y 3$ was associated with BMI in East Asian populations (Wen et al. 2012). Although the functional role of rs6545814 in BMI has not yet been fully demonstrated, one bioinformatics study reported that $r s 6545814$ was an expression quantitative trait loci of the $A D C Y 3$ gene (Yang et al. 2010). Further, it was demonstrated that rs9939609 in FTO had an impact on weight stabilization (Woehning et al. 2013).

One limitation in this study is that there is no further confirmation from other independent subjects. To rectify this limitation, we set aside 601 samples from the total 6,011 samples as a final validation set. Because of this limitation, this study could not identify specific markers for the Korean population, a step which would require additional validation sets. Future studies to build a more appropriate BMI prediction model using Korean-specific markers should be considered. 
192 In summary, we identified 9 BMI-related SNPs in a Korean population using the KARE data.

193 Our results showed upward BMI trends across the samples using a 10-fold cross validation process.

194 Application of our BMI prediction set to a final validation set showed a similar increasing BMI

195 trend when using the wGRS. Although our study has some limitation as described above, the 196 results from the present study might be useful for further BMI-related research. 
197

198

199

200

201

202

203

204

205

206

207

208

209

210

211

212

213

214

215

216

217

218

219

\section{References}

1998. Clinical Guidelines on the Identification, Evaluation, and Treatment of Overweight and Obesity in Adults--The Evidence Report. National Institutes of Health. Obes Res 6 Suppl 2:51S-209S.

Bae S, Choi S, Kim SM, and Park T. 2016. Prediction of Quantitative Traits Using Common Genetic Variants: Application to Body Mass Index. Genomics Inform 14:149-159. 10.5808/GI.2016.14.4.149

Barrett JC, Fry B, Maller J, and Daly MJ. 2005. Haploview: analysis and visualization of LD and haplotype maps. Bioinformatics 21:263-265. 10.1093/bioinformatics/bth457

Bonaccorso S, Sodhi M, Li J, Bobo WV, Chen Y, Tumuklu M, Theleritis C, Jayathilake K, and Meltzer HY. 2015. The brain-derived neurotrophic factor (BDNF) Val66Met polymorphism is associated with increased body mass index and insulin resistance measures in bipolar disorder and schizophrenia. Bipolar Disord 17:528-535. 10.1111/bdi. 12294

Cha S, Koo I, Park BL, Jeong S, Choi SM, Kim KS, Shin HD, and Kim JY. 2011. Genetic Effects of FTO and MC4R Polymorphisms on Body Mass in Constitutional Types. Evid Based Complement Alternat Med 2011:106390. 10.1093/ecam/nep162

Cha SW, Choi SM, Kim KS, Park BL, Kim JR, Kim JY, and Shin HD. 2008. Replication of genetic effects of FTO polymorphisms on BMI in a Korean population. Obesity (Silver Spring) $16: 2187-2189.10 .1038 /$ oby.2008.314

Chen H, Poon A, Yeung C, Helms C, Pons J, Bowcock AM, Kwok PY, and Liao W. 2011. A genetic risk score combining ten psoriasis risk loci improves disease prediction. PLoS One 
6:e19454. 10.1371/journal.pone.0019454

221

Cho YS, Go MJ, Kim YJ, Heo JY, Oh JH, Ban HJ, Yoon D, Lee MH, Kim DJ, Park M, Cha SH, Kim JW, Han BG, Min H, Ahn Y, Park MS, Han HR, Jang HY, Cho EY, Lee JE, Cho NH, Shin C, Park T, Park JW, Lee JK, Cardon L, Clarke G, McCarthy MI, Lee JY, Lee JK, Oh B, and Kim HL. 2009. A large-scale genome-wide association study of Asian populations uncovers genetic factors influencing eight quantitative traits. Nat Genet 41:527-534. $10.1038 / n g .357$

Faul F, Erdfelder E, Buchner A, and Lang AG. 2009. Statistical power analyses using G*Power 3.1: tests for correlation and regression analyses. Behav Res Methods 41:1149-1160. 10.3758/BRM.41.4.1149

Felix JF, Bradfield JP, Monnereau C, van der Valk RJ, Stergiakouli E, Chesi A, Gaillard R, Feenstra B, Thiering E, Kreiner-Moller E, Mahajan A, Pitkanen N, Joro R, Cavadino A, Huikari V, Franks S, Groen-Blokhuis MM, Cousminer DL, Marsh JA, Lehtimaki T, Curtin JA, Vioque J, Ahluwalia TS, Myhre R, Price TS, Vilor-Tejedor N, Yengo L, Grarup N, Ntalla I, Ang W, Atalay M, Bisgaard H, Blakemore AI, Bonnefond A, Carstensen L, Bone Mineral Density in Childhood S, Early G, Lifecourse Epidemiology c, Eriksson J, Flexeder C, Franke L, Geller F, Geserick M, Hartikainen AL, Haworth CM, Hirschhorn JN, Hofman A, Holm JC, Horikoshi M, Hottenga JJ, Huang J, Kadarmideen HN, Kahonen M, Kiess W, Lakka HM, Lakka TA, Lewin AM, Liang L, Lyytikainen LP, Ma B, Magnus P, McCormack SE, McMahon G, Mentch FD, Middeldorp CM, Murray CS, Pahkala K, Pers TH, Pfaffle R, Postma DS, Power C, Simpson A, Sengpiel V, Tiesler CM, Torrent M, Uitterlinden AG, van Meurs JB, Vinding R, Waage J, Wardle J, Zeggini E, Zemel BS, Dedoussis GV, Pedersen O, Froguel P, Sunyer J, Plomin R, Jacobsson B, Hansen T, 

Sorensen TI, Timpson NJ, Grant SF, Jaddoe VW, Early Growth Genetics C, and Bone

Mineral Density in Childhood Study B. 2016. Genome-wide association analysis identifies three new susceptibility loci for childhood body mass index. Hum Mol Genet 25:389-403. $10.1093 / \mathrm{hmg} / \mathrm{ddv} 472$

Hong KW, Lim JE, Go MJ, Shin Cho Y, Ahn Y, Han BG, and Oh B. 2012. Recapitulation of the association of the Val66Met polymorphism of BDNF gene with BMI in Koreans. Obesity (Silver Spring) 20:1871-1875. 10.1038/oby.2011.352

Hung CF, Breen G, Czamara D, Corre T, Wolf C, Kloiber S, Bergmann S, Craddock N, Gill M, Holsboer F, Jones L, Jones I, Korszun A, Kutalik Z, Lucae S, Maier W, Mors O, Owen MJ, Rice J, Rietschel M, Uher R, Vollenweider P, Waeber G, Craig IW, Farmer AE, Lewis CM, Muller-Myhsok B, Preisig M, McGuffin P, and Rivera M. 2015. A genetic risk score combining 32 SNPs is associated with body mass index and improves obesity prediction in people with major depressive disorder. BMC Med 13:86. 10.1186/s12916-015-0334-3

Locke AE, Kahali B, Berndt SI, Justice AE, Pers TH, Day FR, Powell C, Vedantam S, Buchkovich ML, Yang J, Croteau-Chonka DC, Esko T, Fall T, Ferreira T, Gustafsson S, Kutalik Z, Luan J, Magi R, Randall JC, Winkler TW, Wood AR, Workalemahu T, Faul JD, Smith JA, Hua Zhao J, Zhao W, Chen J, Fehrmann R, Hedman AK, Karjalainen J, Schmidt EM, Absher D, Amin N, Anderson D, Beekman M, Bolton JL, Bragg-Gresham JL, Buyske S, Demirkan A, Deng G, Ehret GB, Feenstra B, Feitosa MF, Fischer K, Goel A, Gong J, Jackson AU, Kanoni S, Kleber ME, Kristiansson K, Lim U, Lotay V, Mangino M, Mateo 
Leach I, Medina-Gomez C, Medland SE, Nalls MA, Palmer CD, Pasko D, Pechlivanis S, Peters MJ, Prokopenko I, Shungin D, Stancakova A, Strawbridge RJ, Ju Sung Y, Tanaka T, Teumer A, Trompet S, van der Laan SW, van Setten J, Van Vliet-Ostaptchouk JV, Wang Z, Yengo L, Zhang W, Isaacs A, Albrecht E, Arnlov J, Arscott GM, Attwood AP, Bandinelli S, Barrett A, Bas IN, Bellis C, Bennett AJ, Berne C, Blagieva R, Bluher M, Bohringer S, Bonnycastle LL, Bottcher Y, Boyd HA, Bruinenberg M, Caspersen IH, Ida Chen YD, Clarke R, Daw EW, de Craen AJ, Delgado G, Dimitriou M, Doney AS, Eklund N, Estrada K, Eury E, Folkersen L, Fraser RM, Garcia ME, Geller F, Giedraitis V, Gigante B, Go AS, Golay A, Goodall AH, Gordon SD, Gorski M, Grabe HJ, Grallert H, Grammer TB, Grassler J, Gronberg H, Groves CJ, Gusto G, Haessler J, Hall P, Haller T, Hallmans G, Hartman CA, Hassinen M, Hayward C, Heard-Costa NL, Helmer Q, Hengstenberg C, Holmen O, Hottenga JJ, James AL, Jeff JM, Johansson A, Jolley J, Juliusdottir T, Kinnunen Lichtner P, Lind L, Lindstrom J, Sin Lo K, Lobbens S, Lorbeer R, Lu Y, Mach F, Magnusson PK, Mahajan A, McArdle WL, McLachlan S, Menni C, Merger S, Mihailov E, Milani L, Moayyeri A, Monda KL, Morken MA, Mulas A, Muller G, Muller-Nurasyid M, Musk AW, Nagaraja R, Nothen MM, Nolte IM, Pilz S, Rayner NW, Renstrom F, Rettig Schumacher FR, Scott WR, Seufferlein T, Shi J, Vernon Smith A, Smolonska J, Stanton AV, Steinthorsdottir V, Stirrups K, Stringham HM, Sundstrom J, Swertz MA, Swift AJ, Syvanen AC, Tan ST, Tayo BO, Thorand B, Thorleifsson G, Tyrer JP, Uh HW, Vandenput 
Wright AF, Zhang Q, LifeLines Cohort S, Brennan EP, Choi M, Dastani Z, Drong AW,

Eriksson P, Franco-Cereceda A, Gadin JR, Gharavi AG, Goddard ME, Handsaker RE, Harris TB, Hattersley AT, Hicks AA, Hindorff LA, Hingorani AD, Hofman A, Homuth G, Hovingh GK, Humphries SE, Hunt SC, Hypponen E, Illig T, Jacobs KB, Jarvelin MR, Jockel KH, Johansen B, Jousilahti P, Jukema JW, Jula AM, Kaprio J, Kastelein JJ, Keinanen-Kiukaanniemi SM, Kiemeney LA, Knekt P, Kooner JS, Kooperberg C, Kovacs P, Kraja AT, Kumari M, Kuusisto J, Lakka TA, Langenberg C, Le Marchand L, Lehtimaki T, Lyssenko V, Mannisto S, Marette A, Matise TC, McKenzie CA, McKnight B, Moll FL, 309 Morris AD, Morris AP, Murray JC, Nelis M, Ohlsson C, Oldehinkel AJ, Ong KK, Madden PA, Pasterkamp G, Peden JF, Peters A, Postma DS, Pramstaller PP, Price JF, Qi L, Raitakari OT, Rankinen T, Rao DC, Rice TK, Ridker PM, Rioux JD, Ritchie MD, Rudan 

Zillikens MC, Adair LS, Amouyel P, Asselbergs FW, Assimes TL, Bochud M, Boehm BO, Boerwinkle E, Bornstein SR, Bottinger EP, Bouchard C, Cauchi S, Chambers JC, Chanock SJ, Cooper RS, de Bakker PI, Dedoussis G, Ferrucci L, Franks PW, Froguel P, Groop LC, Haiman CA, Hamsten A, Hui J, Hunter DJ, Hveem K, Kaplan RC, Kivimaki M, Kuh D, Laakso M, Liu Y, Martin NG, Marz W, Melbye M, Metspalu A, Moebus S, Munroe PB, Njolstad I, Oostra BA, Palmer CN, Pedersen NL, Perola M, Perusse L, Peters U, Power C, Quertermous T, Rauramaa R, Rivadeneira F, Saaristo TE, Saleheen D, Sattar N, Schadt EE, Schlessinger D, Slagboom PE, Snieder H, Spector TD, Thorsteinsdottir U, Stumvoll M, Tuomilehto J, Uitterlinden AG, Uusitupa M, van der Harst P, Walker M, Wallaschofski H, Wareham NJ, Watkins H, Weir DR, Wichmann HE, Wilson JF, Zanen P, Borecki IB, AU, Johnson T, Kanoni S, Ladenvall C, Lagou V, Lahti J, Lecoeur C, Liu Y, MartinezLarrad MT, Montasser ME, Navarro P, Perry JR, Rasmussen-Torvik LJ, Salo P, Sattar N, Shungin D, Strawbridge RJ, Tanaka T, van Duijn CM, An P, de Andrade M, Andrews JS, 
Aspelund T, Atalay M, Aulchenko Y, Balkau B, Bandinelli S, Beckmann JS, Beilby JP,

Bellis C, Bergman RN, Blangero J, Boban M, Boehnke M, Boerwinkle E, Bonnycastle LL,

Boomsma DI, Borecki IB, Bottcher Y, Bouchard C, Brunner E, Budimir D, Campbell H, Carlson O, Chines PS, Clarke R, Collins FS, Corbaton-Anchuelo A, Couper D, de Faire U, Dedoussis GV, Deloukas P, Dimitriou M, Egan JM, Eiriksdottir G, Erdos MR, Eriksson JG, Eury E, Ferrucci L, Ford I, Forouhi NG, Fox CS, Franzosi MG, Franks PW, Frayling TM, Froguel P, Galan P, de Geus E, Gigante B, Glazer NL, Goel A, Groop L, Gudnason V, Hallmans G, Hamsten A, Hansson O, Harris TB, Hayward C, Heath S, Hercberg S, Hicks AA, Hingorani A, Hofman A, Hui J, Hung J, Jarvelin MR, Jhun MA, Johnson PC, Jukema JW, Jula A, Kao WH, Kaprio J, Kardia SL, Keinanen-Kiukaanniemi S, Kivimaki M, Kolcic I, Kovacs P, Kumari M, Kuusisto J, Kyvik KO, Laakso M, Lakka T, Lannfelt L, Lathrop GM, Launer LJ, Leander K, Li G, Lind L, Lindstrom J, Lobbens S, Loos RJ, Luan J, Lyssenko V, Magi R, Magnusson PK, Marmot M, Meneton P, Mohlke KL, Mooser V, Morken MA, Miljkovic I, Narisu N, O'Connell J, Ong KK, Oostra BA, Palmer LJ, Palotie A, Pankow JS, Peden JF, Pedersen NL, Pehlic M, Peltonen L, Penninx B, Pericic M, Perola M, Perusse L, Peyser PA, Polasek O, Pramstaller PP, Province MA, Raikkonen K, Rauramaa R, Rehnberg E, Rice K, Rotter JI, Rudan I, Ruokonen A, Saaristo T, Sabater-

Rios M, Shuldiner AR, Sijbrands EJ, Siscovick DS, Smit JH, Small KS, Smith NL, Smith AV, Stancakova A, Stirrups K, Stumvoll M, Sun YV, Swift AJ, Tonjes A, Tuomilehto J, 355 Trompet S, Uitterlinden AG, Uusitupa M, Vikstrom M, Vitart V, Vohl MC, Voight BF, 356 Vollenweider P, Waeber G, Waterworth DM, Watkins H, Wheeler E, Widen E, Wild SH, 357 Willems SM, Willemsen G, Wilson JF, Witteman JC, Wright AF, Yaghootkar H, Zelenika 
358

359

360

361

362

363

364

365

366

367

368

369

370

371

372

373

374

375

376

377

378

379 380

D, Zemunik T, Zgaga L, Replication DIG, Meta-analysis C, Multiple Tissue Human Expression Resource C, Wareham NJ, McCarthy MI, Barroso I, Watanabe RM, Florez JC, Dupuis J, Meigs JB, and Langenberg C. 2012. A genome-wide approach accounting for body mass index identifies genetic variants influencing fasting glycemic traits and insulin resistance. Nat Genet 44:659-669. 10.1038/ng.2274

Monnereau C, Jansen PW, Tiemeier H, Jaddoe VW, and Felix JF. 2017. Influence of genetic variants associated with body mass index on eating behavior in childhood. Obesity (Silver Spring). 10.1002/oby.21778

Munoz-Yanez C, Perez-Morales R, Moreno-Macias H, Calleros-Rincon E, Ballesteros G, Gonzalez RA, and Espinosa J. 2016. Polymorphisms FTO rs9939609, PPARG rs1801282 and ADIPOQ rs4632532 and rs182052 but not lifestyle are associated with obesity relatedtraits in Mexican children. Genet Mol Biol 39:547-553. 10.1590/1678-4685-GMB-20150267

Neocleous V, Shammas C, Phelan MM, Fanis P, Pantelidou M, Skordis N, Mantzoros C, Phylactou LA, and Toumba M. 2016. A novel MC4R deletion coexisting with FTO and MC1R gene variants, causes severe early onset obesity. Hormones (Athens) 15:445-452. 10.14310/horm.2002.1686

Palmieri O, Bossa F, Valvano MR, Corritore G, Latiano T, Martino G, D'Inca R, Cucchiara S, Pastore M, D'Altilia M, Scimeca D, Biscaglia G, Andriulli A, and Latiano A. 2017. Crohn's Disease Localization Displays Different Predisposing Genetic Variants. PLoS One 12:e0168821. 10.1371/journal.pone.0168821

Peterson RE, Maes HH, Lin P, Kramer JR, Hesselbrock VM, Bauer LO, Nurnberger JI, Jr., Edenberg HJ, Dick DM, and Webb BT. 2014. On the association of common and rare 
genetic variation influencing body mass index: a combined SNP and CNV analysis. $B M C$ Genomics 15:368. 10.1186/1471-2164-15-368

383

384

385

386

387

388

389

390

391

392

393

394

395

396

397

398

399

400

401

402

403

Sandholt CH, Sparso T, Grarup N, Albrechtsen A, Almind K, Hansen L, Toft U, Jorgensen T, Hansen T, and Pedersen O. 2010. Combined analyses of 20 common obesity susceptibility variants. Diabetes 59:1667-1673. 10.2337/db09-1042

Speliotes EK, Willer CJ, Berndt SI, Monda KL, Thorleifsson G, Jackson AU, Lango Allen H, Lindgren CM, Luan J, Magi R, Randall JC, Vedantam S, Winkler TW, Qi L, Workalemahu T, Heid IM, Steinthorsdottir V, Stringham HM, Weedon MN, Wheeler E, Wood AR, Ferreira T, Weyant RJ, Segre AV, Estrada K, Liang L, Nemesh J, Park JH, Gustafsson S, Kilpelainen TO, Yang J, Bouatia-Naji N, Esko T, Feitosa MF, Kutalik Z, Mangino M, Raychaudhuri S, Scherag A, Smith AV, Welch R, Zhao JH, Aben KK, Absher DM, Amin N, Dixon AL, Fisher E, Glazer NL, Goddard ME, Heard-Costa NL, Hoesel V, Hottenga JJ, Johansson A, Johnson T, Ketkar S, Lamina C, Li S, Moffatt MF, Myers RH, Narisu N, Perry JR, Peters MJ, Preuss M, Ripatti S, Rivadeneira F, Sandholt C, Scott LJ, Timpson NJ, Tyrer JP, van Wingerden S, Watanabe RM, White CC, Wiklund F, Barlassina C, Chasman DI, Cooper MN, Jansson JO, Lawrence RW, Pellikka N, Prokopenko I, Shi J, Thiering E, Alavere H, Alibrandi MT, Almgren P, Arnold AM, Aspelund T, Atwood LD, Balkau B, Balmforth AJ, Bennett AJ, Ben-Shlomo Y, Bergman RN, Bergmann S, Biebermann H, Blakemore AI, Boes T, Bonnycastle LL, Bornstein SR, Brown MJ, Buchanan TA, Busonero F, Campbell H, Cappuccio FP, Cavalcanti-Proenca C, Chen YD, Chen CM, Chines PS, Clarke R, Coin L, Connell J, Day IN, den Heijer M, Duan J, Ebrahim S, Elliott P, Elosua R, Eiriksdottir G, Erdos MR, Eriksson JG, Facheris MF, Felix SB, Fischer-Posovszky P, Folsom AR, Friedrich N, Freimer NB, Fu M, Gaget S, Gejman PV, 
Geus EJ, Gieger C, Gjesing AP, Goel A, Goyette P, Grallert H, Grassler J, Greenawalt 405 DM, Groves CJ, Gudnason V, Guiducci C, Hartikainen AL, Hassanali N, Hall AS, Havulinna AS, Hayward C, Heath AC, Hengstenberg C, Hicks AA, Hinney A, Hofman A, Homuth G, Hui J, Igl W, Iribarren C, Isomaa B, Jacobs KB, Jarick I, Jewell E, John U, Jorgensen T, Jousilahti P, Jula A, Kaakinen M, Kajantie E, Kaplan LM, Kathiresan S, Kettunen J, Kinnunen L, Knowles JW, Kolcic I, Konig IR, Koskinen S, Kovacs P, Kuusisto J, Kraft P, Kvaloy K, Laitinen J, Lantieri O, Lanzani C, Launer LJ, Lecoeur C, Lehtimaki T, Lettre G, Liu J, Lokki ML, Lorentzon M, Luben RN, Ludwig B, Magic, Manunta P, 412 Marek D, Marre M, Martin NG, McArdle WL, McCarthy A, McKnight B, Meitinger T, Melander O, Meyre D, Midthjell K, Montgomery GW, Morken MA, Morris AP, Mulic R, Ngwa JS, Nelis M, Neville MJ, Nyholt DR, O'Donnell CJ, O'Rahilly S, Ong KK, Oostra B, Pare G, Parker AN, Perola M, Pichler I, Pietilainen KH, Platou CG, Polasek O, Pouta A, Rafelt S, Raitakari O, Rayner NW, Ridderstrale M, Rief W, Ruokonen A, Robertson NR, Rzehak P, Salomaa V, Sanders AR, Sandhu MS, Sanna S, Saramies J, Savolainen MJ, Scherag S, Schipf S, Schreiber S, Schunkert H, Silander K, Sinisalo J, Siscovick DS, Smit JH, Soranzo N, Sovio U, Stephens J, Surakka I, Swift AJ, Tammesoo ML, Tardif JC, Teder-Laving M, Teslovich TM, Thompson JR, Thomson B, Tonjes A, Tuomi T, van Meurs JB, van Ommen GJ, Vatin V, Viikari J, Visvikis-Siest S, Vitart V, Vogel CI, Voight BF, Waite LL, Wallaschofski H, Walters GB, Widen E, Wiegand S, Wild SH, Willemsen G, Witte DR, Witteman JC, Xu J, Zhang Q, Zgaga L, Ziegler A, Zitting P, Beilby JP, 424 Farooqi IS, Hebebrand J, Huikuri HV, James AL, Kahonen M, Levinson DF, Macciardi F, Nieminen MS, Ohlsson C, Palmer LJ, Ridker PM, Stumvoll M, Beckmann JS, Boeing H, 426 Boerwinkle E, Boomsma DI, Caulfield MJ, Chanock SJ, Collins FS, Cupples LA, Smith 
GD, Erdmann J, Froguel P, Gronberg H, Gyllensten U, Hall P, Hansen T, Harris TB, Hattersley AT, Hayes RB, Heinrich J, Hu FB, Hveem K, Illig T, Jarvelin MR, Kaprio J, Karpe F, Khaw KT, Kiemeney LA, Krude H, Laakso M, Lawlor DA, Metspalu A, Munroe PB, Ouwehand WH, Pedersen O, Penninx BW, Peters A, Pramstaller PP, Quertermous T, Reinehr T, Rissanen A, Rudan I, Samani NJ, Schwarz PE, Shuldiner AR, Spector TD, Tuomilehto J, Uda M, Uitterlinden A, Valle TT, Wabitsch M, Waeber G, Wareham NJ, Watkins H, Procardis C, Wilson JF, Wright AF, Zillikens MC, Chatterjee N, McCarroll SA, Purcell S, Schadt EE, Visscher PM, Assimes TL, Borecki IB, Deloukas P, Fox CS, Groop LC, Haritunians T, Hunter DJ, Kaplan RC, Mohlke KL, O'Connell JR, Peltonen L, Schlessinger D, Strachan DP, van Duijn CM, Wichmann HE, Frayling TM, Thorsteinsdottir U, Abecasis GR, Barroso I, Boehnke M, Stefansson K, North KE, McCarthy MI, Hirschhorn JN, Ingelsson E, and Loos RJ. 2010. Association analyses of 249,796 individuals reveal 18 new loci associated with body mass index. Nat Genet 42:937-948. 10.1038/ng.686

Thanassoulis G, Peloso GM, Pencina MJ, Hoffmann U, Fox CS, Cupples LA, Levy D, D'Agostino RB, Hwang SJ, and O'Donnell CJ. 2012. A genetic risk score is associated with incident cardiovascular disease and coronary artery calcium: the Framingham Heart Study. Circ Cardiovasc Genet 5:113-121. 10.1161/CIRCGENETICS.111.961342

Wen W, Cho YS, Zheng W, Dorajoo R, Kato N, Qi L, Chen CH, Delahanty RJ, Okada Y, Tabara Y, Gu D, Zhu D, Haiman CA, Mo Z, Gao YT, Saw SM, Go MJ, Takeuchi F, Chang LC, Kokubo Y, Liang J, Hao M, Le Marchand L, Zhang Y, Hu Y, Wong TY, Long J, Han BG, Kubo M, Yamamoto K, Su MH, Miki T, Henderson BE, Song H, Tan A, He J, Ng DP, Cai Q, Tsunoda T, Tsai FJ, Iwai N, Chen GK, Shi J, Xu J, Sim X, Xiang YB, Maeda S, Ong 
450

451

452

453

454

455

456

457

458

459

460

461

462

463

464

465

466

467

468

469

470

471

472

RT, Li C, Nakamura Y, Aung T, Kamatani N, Liu JJ, Lu W, Yokota M, Seielstad M, Fann CS, Genetic Investigation of ATC, Wu JY, Lee JY, Hu FB, Tanaka T, Tai ES, and Shu XO. 2012. Meta-analysis identifies common variants associated with body mass index in east Asians. Nat Genet 44:307-311. 10.1038/ng.1087

Woehning A, Schultz JH, Roeder E, Moeltner A, Isermann B, Nawroth PP, Wolfrum C, and Rudofsky G. 2013. The A-allele of the common FTO gene variant rs9939609 complicates weight maintenance in severe obese patients. Int $J$ Obes (Lond) 37:135-139. 10.1038/ijo.2012.14

Yang J, Loos RJ, Powell JE, Medland SE, Speliotes EK, Chasman DI, Rose LM, Thorleifsson G, Steinthorsdottir V, Magi R, Waite L, Smith AV, Yerges-Armstrong LM, Monda KL, Hadley D, Mahajan A, Li G, Kapur K, Vitart V, Huffman JE, Wang SR, Palmer C, Esko T, Fischer K, Zhao JH, Demirkan A, Isaacs A, Feitosa MF, Luan J, Heard-Costa NL, White C, Jackson AU, Preuss M, Ziegler A, Eriksson J, Kutalik Z, Frau F, Nolte IM, Van VlietOstaptchouk JV, Hottenga JJ, Jacobs KB, Verweij N, Goel A, Medina-Gomez C, Estrada K, Bragg-Gresham JL, Sanna S, Sidore C, Tyrer J, Teumer A, Prokopenko I, Mangino M, Lindgren CM, Assimes TL, Shuldiner AR, Hui J, Beilby JP, McArdle WL, Hall P, Haritunians T, Zgaga L, Kolcic I, Polasek O, Zemunik T, Oostra BA, Junttila MJ, Gronberg H, Schreiber S, Peters A, Hicks AA, Stephens J, Foad NS, Laitinen J, Pouta A, Kaakinen M, Willemsen G, Vink JM, Wild SH, Navis G, Asselbergs FW, Homuth G, John U, Iribarren C, Harris T, Launer L, Gudnason V, O'Connell JR, Boerwinkle E, Cadby G, Palmer LJ, James AL, Musk AW, Ingelsson E, Psaty BM, Beckmann JS, Waeber G, Vollenweider P, Hayward C, Wright AF, Rudan I, Groop LC, Metspalu A, Khaw KT, van Duijn CM, Borecki IB, Province MA, Wareham NJ, Tardif JC, Huikuri HV, Cupples LA, 
473

474

475

476

477

478

479

480

481

482

483

484

485

486

487

Atwood LD, Fox CS, Boehnke M, Collins FS, Mohlke KL, Erdmann J, Schunkert H, Hengstenberg C, Stark K, Lorentzon M, Ohlsson C, Cusi D, Staessen JA, Van der Klauw MM, Pramstaller PP, Kathiresan S, Jolley JD, Ripatti S, Jarvelin MR, de Geus EJ, Boomsma DI, Penninx B, Wilson JF, Campbell H, Chanock SJ, van der Harst P, Hamsten A, Watkins H, Hofman A, Witteman JC, Zillikens MC, Uitterlinden AG, Rivadeneira F, Zillikens MC, Kiemeney LA, Vermeulen SH, Abecasis GR, Schlessinger D, Schipf S, Stumvoll M, Tonjes A, Spector TD, North KE, Lettre G, McCarthy MI, Berndt SI, Heath AC, Madden PA, Nyholt DR, Montgomery GW, Martin NG, McKnight B, Strachan DP, Hill WG, Snieder H, Ridker PM, Thorsteinsdottir U, Stefansson K, Frayling TM, Hirschhorn JN, Goddard ME, and Visscher PM. 2012. FTO genotype is associated with phenotypic variability of body mass index. Nature 490:267-272. 10.1038/nature11401

Yang TP, Beazley C, Montgomery SB, Dimas AS, Gutierrez-Arcelus M, Stranger BE, Deloukas P, and Dermitzakis ET. 2010. Genevar: a database and Java application for the analysis and visualization of SNP-gene associations in eQTL studies. Bioinformatics 26:2474-2476. 10.1093/bioinformatics/btq452 
489

490

491

492

493

494

495

496

497

498

499

500

501

\section{Figure Legend}

Figure 1. Analysis flow chart used in the present study.

Figure 2. Analysis results applying the wGRS of the 9 selected SNPs to the SNP selection set and to the final validation set. The BMI trends of each analysis group are displayed using their standard curve with the overall $P$-values and $\mathrm{R}^{2}$. The black closed and punctured circles represent the BMI values of each wGRS section in the SNP selection and validation set, respectively. The black and red dashed lines are the standard curves for the SNP selection and validation set. A. BMI trends of SNP selection set and validation set using total subjects. B. BMI trends of SNP selection set and validation set using male samples. C. BMI trends of SNP selection set and validation set using female samples. 


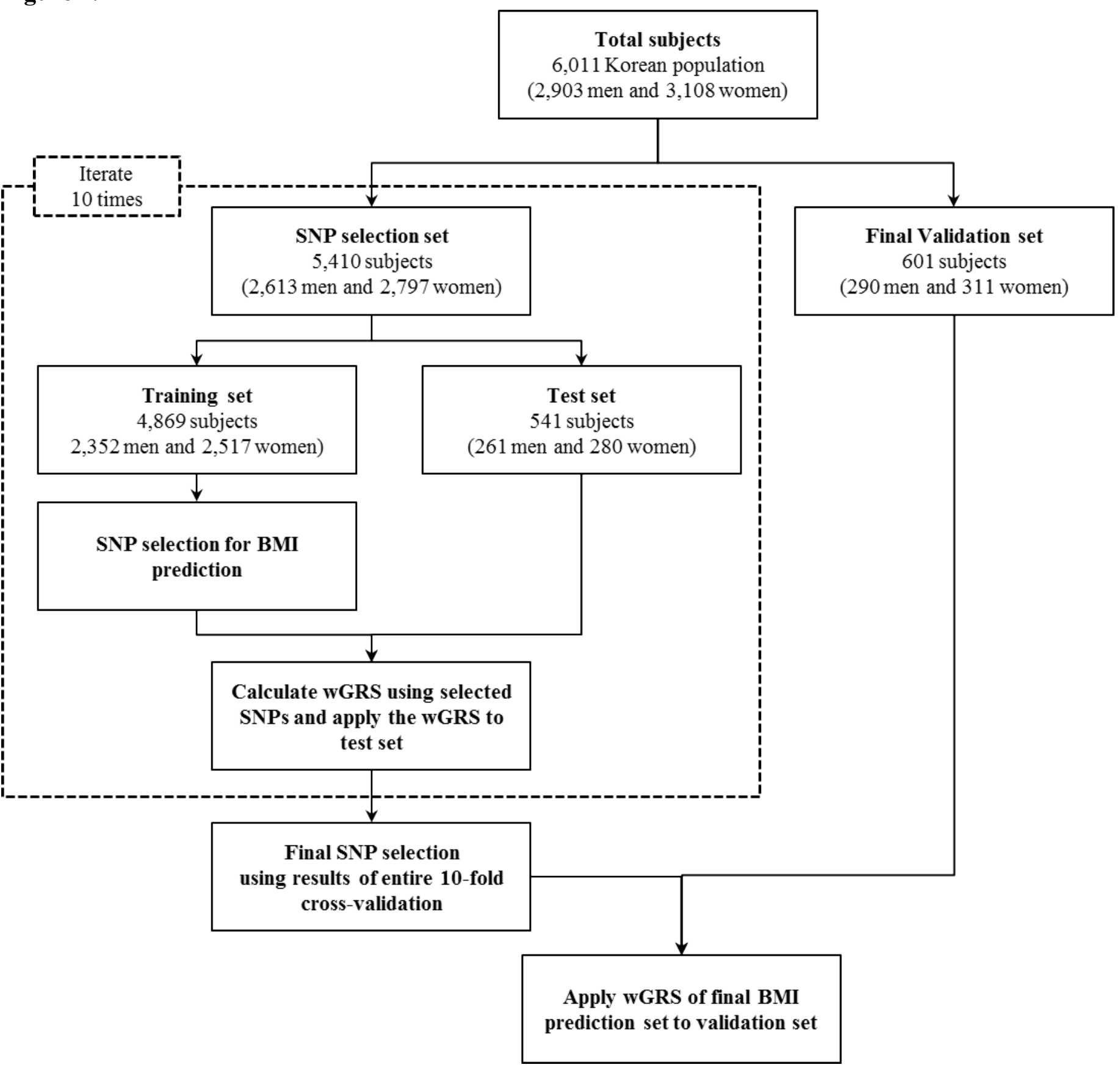




\section{Figure 2}

A.

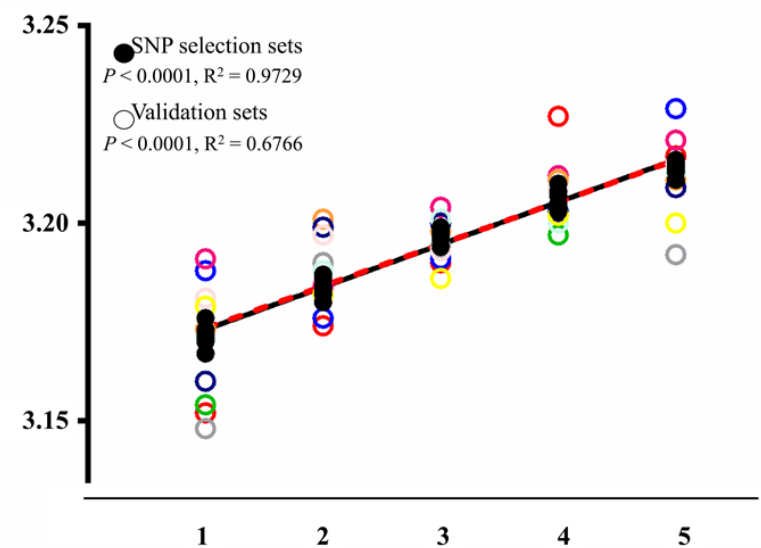

B.

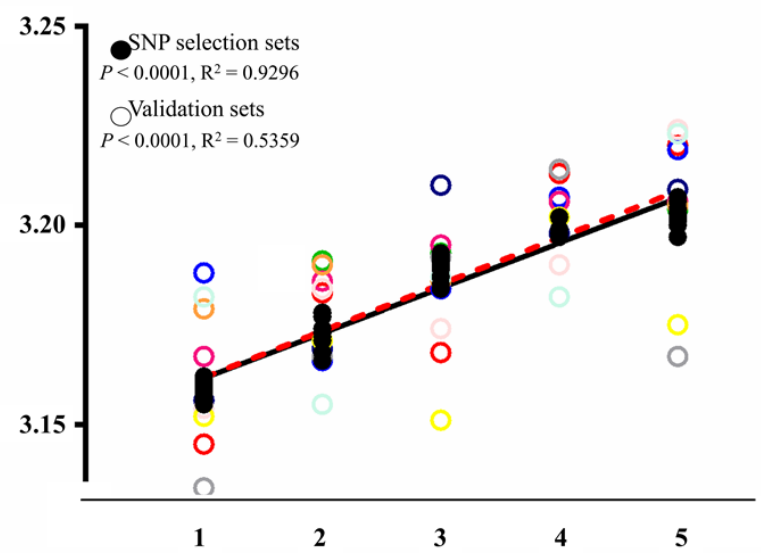

C.

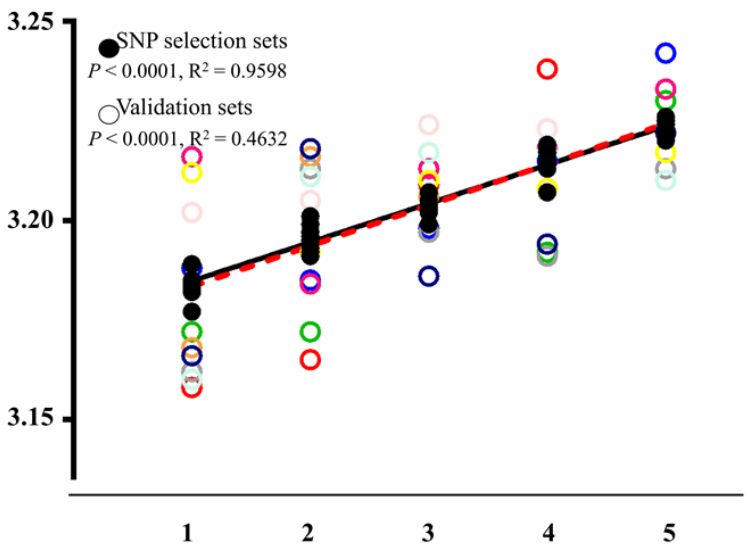


Table 1. Results of regression analysis and allele information using SNP selection set including additionally constructed sets

\begin{tabular}{|c|c|c|c|c|c|c|c|c|c|c|c|c|c|c|c|c|c|c|}
\hline \multirow{2}{*}{$\begin{array}{l}\square \\
\text { Markers }\end{array}$} & \multirow{2}{*}{ Gene } & \multirow{2}{*}{$\begin{array}{l}\square \\
\text { Location }\end{array}$} & \multirow{2}{*}{$\begin{array}{l} \\
\text { Position }\end{array}$} & \multicolumn{3}{|c|}{$P \quad P$-values } & \multicolumn{5}{|c|}{$\square \quad$ Allele information } & \multicolumn{4}{|c|}{$\square$ Genotype Count with BMI average } & \multirow{2}{*}{$\begin{array}{l}\square \\
\square\end{array}$} & $\square$ & \multirow[b]{2}{*}{$\begin{array}{l}\text { GWAS } \\
\text { catalog }\end{array}$} \\
\hline & & & & $\square$ & $\begin{array}{l}\text { Present } \\
\text { study }\end{array}$ & $\begin{array}{l}\text { GWAS } \\
\text { catalog }\end{array}$ & $\square$ & $\begin{array}{l}\text { BMI } \\
\text { increasing }\end{array}$ & Minor & Major & MAF & $\square$ & $\begin{array}{l}\text { C/C } \\
\text { (BMI log.) }\end{array}$ & $\begin{array}{l}\mathrm{C} / \mathrm{R} \\
\text { (BMI log.) }\end{array}$ & $\begin{array}{l}\text { R/R } \\
\text { (BMI log.) }\end{array}$ & & $\mathrm{LD}(\mathrm{r} 2>0.8)$ & \\
\hline rs 12566985 & FPGT-TNNI3K & 1:74536509 & Intron & $\square$ & $0.001-0.03$ & $2.00 \times 10^{-10}$ & $\square$ & G & A & G & 0.11 & $\square$ & $\begin{array}{l}4260 \\
(3.197)\end{array}$ & $\begin{array}{l}1061 \\
(3.187)\end{array}$ & $\begin{array}{l}89 \\
(3.169)\end{array}$ & $\square$ & - & $\begin{array}{l}\text { (Felix et al. } \\
2016 \text { ) }\end{array}$ \\
\hline$r s 6545809$ & $A D C Y 3$ & 2:24903846 & Intron & $\square$ & $0.002-0.02$ & $6.00 \times 10^{-9}$ & $\square$ & $\mathrm{T}$ & $\mathrm{T}$ & $\mathrm{C}$ & 0.44 & $\square$ & $\begin{array}{l}1705 \\
(3.191)\end{array}$ & $\begin{array}{l}2660 \\
(3.193)\end{array}$ & $\begin{array}{l}1045 \\
(3.204)\end{array}$ & $\square$ & $r s 10182181$ & $\begin{array}{l}\text { (Locke et } \\
\text { al. 2015) }\end{array}$ \\
\hline$r s 2943634$ & - & 2:226203364 & Intergenic & $\square$ & $0.0002-0.02$ & $2.00 \times 10^{-14}$ & $\square$ & $\mathrm{C}$ & A & $\mathrm{C}$ & 0.08 & $\square$ & $\begin{array}{l}4577 \\
(3.197)\end{array}$ & $\begin{array}{l}805 \\
(3.182)\end{array}$ & $\begin{array}{l}28 \\
(3.184)\end{array}$ & $\square$ & - & $\begin{array}{l}\text { (Manning } \\
\text { et al. 2012) }\end{array}$ \\
\hline rs734597 & - & 6:50868566 & Intergenic & $\square$ & $0.0007-0.04$ & $3.00 \times 10^{-20}$ & $\square$ & A & A & G & 0.19 & $\square$ & $\begin{array}{l}3547 \\
(3.192)\end{array}$ & $\begin{array}{l}1680 \\
(3.199)\end{array}$ & $\begin{array}{l}183 \\
(3.202)\end{array}$ & $\square$ & rs 987237 & $\begin{array}{l}\text { (Speliotes } \\
\text { et al. 2010) }\end{array}$ \\
\hline rs11030104 & $B D N F$ & 11:27662970 & Intron & $\square$ & $0.0004-0.006$ & $5.00 \times 10^{-19}$ & $\square$ & A & G & A & 0.45 & $\square$ & $\begin{array}{l}1617 \\
(3.200)\end{array}$ & $\begin{array}{l}2708 \\
(3.195)\end{array}$ & $\begin{array}{l}1085 \\
(3.184)\end{array}$ & $\square$ & - & $\begin{array}{l}\text { (Locke et } \\
\text { al. 2015) }\end{array}$ \\
\hline rs7988412 & GTF3A & $13: 27426145$ & Intron & $\square$ & $0.001-0.02$ & $2.00 \times 10^{-7}$ & $\square$ & $\mathrm{T}$ & $\mathrm{T}$ & $\mathrm{C}$ & 0.13 & $\square$ & $\begin{array}{l}4053 \\
(3.192)\end{array}$ & $\begin{array}{l}1275 \\
(3.203)\end{array}$ & $\begin{array}{l}82 \\
(3.197)\end{array}$ & $\square$ & $r s 12016871$ & $\begin{array}{l}\text { (Locke et } \\
\text { al. 2015) }\end{array}$ \\
\hline$r s 2241423$ & $M A P 2 K 5$ & 15:67794500 & Intron & $\square$ & $0.008-0.04$ & $1.00 \times 10^{-18}$ & $\square$ & G & G & A & 0.37 & $\square$ & $\begin{array}{l}2162 \\
(3.192)\end{array}$ & $\begin{array}{l}2508 \\
(3.193)\end{array}$ & $\begin{array}{l}740 \\
(3.205)\end{array}$ & $\square$ & - & $\begin{array}{l}\text { (Speliotes } \\
\text { et al. 2010) }\end{array}$ \\
\hline$r s 7202116$ & FTO & $16: 53787703$ & Intron & $\square$ & $0.00004-0.0006$ & $2.00 \times 10^{-10}$ & $\square$ & G & G & A & 0.13 & $\square$ & $\begin{array}{l}4143 \\
(3.191)\end{array}$ & $\begin{array}{l}1162 \\
(3.206)\end{array}$ & $\begin{array}{l}105 \\
(3.202)\end{array}$ & $\square$ & - & $\begin{array}{l}\text { (Yang etal. } \\
\text { 2012) }\end{array}$ \\
\hline rs 6567160 & - & 18:60161902 & Intergenic & $\square$ & $0.00006-0.002$ & $5.00 \times 10^{-30}$ & $\square$ & $\mathrm{C}$ & $\mathrm{C}$ & $\mathrm{T}$ & 0.24 & $\square$ & $\begin{array}{l}3101 \\
(3.190)\end{array}$ & $\begin{array}{l}1979 \\
(3.198)\end{array}$ & $\begin{array}{l}330 \\
(3.212)\end{array}$ & $\square$ & - & $\begin{array}{l}\text { (Locke et } \\
\text { al. 2015) }\end{array}$ \\
\hline
\end{tabular}

Gene name and location and position of the SNPs were obtained from the NCBI database. The $P$-values were calculated using logistic regression on the SNP selection set as well as on the additional re-constructed sets (10 sets). Hyphens (-) indicate that there was no data available or it was not applicable. $\mathrm{C} / \mathrm{C}, \mathrm{C} / \mathrm{R}$, and R/R represent the homozygote of the major allele, and the heterozygote and homozygote of the minor allele, respectively. The SNPs in the LD column are those reported in previous GWAS and were used in the present study. BMI, Body Mass Index; MAF, Minor allele frequency; LD, Linkage Disequilibrium. 